KAZIMIERZ KRZAKIEWICZ SZYMON CYFERT

\title{
Dynamic capabilities in strategic choice processes within organisations ${ }^{\prime}$
}

Prof. Kazimierz Krzakiewicz, PUE

Poznań University of Economics

Prof. Szymon Cyfert, PUE

Poznań University of Economics

\section{Introduction}

Recent years have seen a significant shift in views on the nature of the internal organisational environment and its role in strategic choice processes. One consequence of that shift is the emergence of the resourcebased view of the firm and its developmental offshoot - the dynamic capabilities concept. Even though attractive in terms of the insights it has to offer, the dynamic capabilities concept remains to a large extent theoretically undefined.

The purpose of this article is to systematise different approaches to the dynamic capabilities concept as they are found in the existing literature, with a particular focus on its relevance to modern-day organisations as a tool to increase their competitiveness. The other goal is to discuss two issues that are critical to the dynamic capabilities concept. Firstly, what are the conditions for the predominant role of dynamic capabilities in the area of strategic management? Secondly, can the dynamic capabilities concept be

1 Projekt został sfinansowany ze środków Narodowego Centrum Nauki przyznanych na podstawie decyzji numer DEC-2013/11/B/HS4/00697 
treated as an underlying theoretical and methodological framework for strategic choices in modern-day organisations?

The article draws upon the existing literature to discuss different notions used in the resource-based view and the dynamic capabilities concept, and then attempts to sketch out their essence and determine their interrelationships in strategic choice processes. A particular attention was paid to the content, forms and role of dynamic capabilities. This made it possible to propose their classification model. The concluding part of the article presents the author's point of view on the nature of core competencies and their role in securing a competitive advantage for an organisation.

\section{The origin of the dynamic capabilities concept}

The research into processes that build long-term competitive advantages and the management practice both testify to the growing importance of the resource-based view of the firm. Under the resource-based perspective, the free movement of capital, goods, labour, information and knowledge within the global economic system has reduced competitive barriers and limitations, which has translated into a greater availability of resources and complexity of processes in modern-day organisations' immediate environment. The resourcebased view makes a distinction between resources and competencies and assumes that organisations build the latter by acquiring and using resources. Organisational competencies then affect the resources and make it possible to have them transformed into new configurations in line with specific operational activities.

Against the background of ever-increasing environmental instabilities, a growing importance of intangible organisational resources, the impact of tacit knowledge on decision-making processes, the development of informal relationships with stakeholders and a growing importance of business process architectures, the research on dynamic capabilities in organisations has led to separation of that concept from the resourced-based perspective and recognition of its status as a research area in its own right. The relevance and topicality of this area of research stem from the need to look for the sources of competitive advantages and the factors that determine their sustainability in a long-term perspective.

Strategic choice-making is more and more focused on the interrelationships between strategy and the organisation's internal environment. The organisation's long-term competitiveness cannot be based solely on manufacturing 
competitiveness and the high level of risk borne by potential imitators. Accepting this assumption means that a sustained competitive advantage is not synonymous with manufacturing competitiveness. Price and product quality advantages can be quickly eroded by competitors and may fail to bring their expected benefits.

It should be noted that while the proponents of the resource-based perspective, and especially advocates of the dynamic capabilities concept, agree as to where the sources of competitive advantages should be sought, there is no agreement between them about the nuts and bolts of how those advantages are built and about the significance of certain fundamental categories underlying this process.

\section{The dynamic capabilities concept: an attempt to reconstruct and systematise terms}

B. Wernerfelt (1984) defines resources broadly as anything that could be treated as a strength or weakness of an organisation. J. Barney (1991) takes the definition even further and says that resources include all assets, capabilities, organisational processes, organisational attributes, information, knowledge, etc, which are controlled by an organisation and enable it to formulate and implement strategies that improve its efficiency and production effectiveness. $R$. Grant sees the nature of resources differently and believes they are the source of the organisation's capabilities; capabilities, on the other hand, are the main source of organisation's competitive advantage. In his definition of the construct of capabilities, G. Richardson (1972) indicates that they include knowledge, skills and experience relating to a variety of production activities. Some of these capabilities are inter-related and as such require similar resources; other may be complementary both in technical and economic terms, which means they complement each other in a process of production and their use must be co-ordinated (Richardson 1972). S. G. Winter (2003) emphasizes the value of capabilities and defines the category of organisational capability as a high-level routine or a collection of routines that, together with its implementing input flows, provide the organisation's management with a number of alternative options for ensuring results that meet specific expectations (Winter 2003).

B. Loasby (1998) notes that capabilities are a specific kind of knowledge: "knowing-how" as opposed to "knowing the". J. Teece, H. Pizano, E. Shuen (1997) think of capabilities as the organisation's specific capacity to integrate, build and reconfigure internal and external organizational

9 
competencies to match the requirements of a fast-changing environment in order to achieve new and innovative forms of competitive advantage. B. Kogut and W. Zander (2002) introduce the concept of "combinative capabilities" which they understand as the organisational ability to synthetise and acquire intellectual resources and then generate their new applications. For R. Amit and C. Schoemaker (1993), dynamic capabilities are repeated process or product innovations, manufacturing flexibility, responsiveness to environmental trends. While R. Amit and C. Schoemaker define dynamic capabilities from the perspective of the firm's environment, C. Helfat (2009) looks at them from within the organisation and defines dynamic capabilities as the capacity of an organization to create, extend and improve its resource base. $\mathrm{K}$. Eisenhardt and J. Martin (2000) define dynamic capabilities in a slightly different manner as the firm's processes that use resources, (including in particular the processes to integrate, reconfigure, gain and release resources) to match and create changes in the environment. M. Zollo and S. Winter (2002), who skip over the issue of resources and instead focus on the organisation's operational routines, propose that dynamic capabilities are a learned and stable pattern of collective activity through which the organisation systematically generates and modifies its operating routines in pursuit of improved managerial effectiveness.

D. Teece (2009) defines competencies as discrete business processes of an organisation which underlie its management processes, and also organisationwide habits. R. Sanchez, A. Heene and H. Thomas (1996) take this definition further and propose that competencies make up the whole of organisational processes and current operations relating to the integrated coordinated deployment of resources and assets.

H. Hamel and K. Prahalad (2002) define core competencies as habits and skills that allow a firm to deliver fundamental benefits to its customers. K. Andrews (1980) uses the term "distinctive competence" to refer to an organisation's superior operating ability: "it is something more than what the organisation can do, it is what the organisation can do particularly well."

What these definitional approaches to what are fundamental terms for dynamic capabilities concept show is that the notion of "resource" has different contextual applications within the resource-based view. The fact that there is no clear-cut definitional approach to these terms makes it impossible to identify the firm's competitive advantages. It is therefore difficult to say with certainty what distinguishes a "resource" from a "non-resource". 


\section{Sources of competitive advantages: capabilities v. competencies}

Traditionally, "organisational resources" are defined as all available resources, capabilities, organisational processes, information, knowledge, etc., which are controlled by an organisation and enable it to formulate strategies and effectively implement strategic options. The theory of strategic management, on the other hand, defines resources as strengths of an organisation which shape its strategic position. In this approach, a resource is thought of as valuable if it secures a competitive advantage in the resource markets and helps to maintain favourable competitive positions in the goods market. In the resource-based perspective, valuable and rare resources can thus become the basis for providing competitive advantage only if competitors do not have them and are unable to obtain them going forward. Resources of this kind are hard to imitate, especially if (Dierickx , Cool, 1999):

- there are unique conditions of development,

- the relationship between a resource and a competitive advantage is not clearly defined,

- there is a complex organizational culture.

In the resource-based view, sources of long-term competitive advantages include the resource base of an organisation and certain variables which affect the efficiency of the management and resource shaping and integration processes. The unique nature of an organisation and its behaviours stems from its resources and capabilities and the way it coordinates them internally. According to this perspective, resources are thought of as tangible and intangible assets of an organisation that are used as factors of production, for exchange in the market, or as assets that carry certain value for market participants or provide economic rent of some other kind.

The theoretical foundations for how "capabilities" are built were laid out in the evolutionary theory of S. Winter and R. Nelson (1982) who believe that regularities in behavioural patterns of organisations or individuals may be identified as "organisational routines" (capabilities). The result of organisational learning processes, routines are a way of gaining tacit knowledge which is unavailable to competitors. According to S. Winter and R. Nelson, this is what makes the organisational resource-using capabilities their unique character.

The existing literature describes a number of different approaches to defining the relationship between the concepts of "capabilities" and "competencies". Based on those approaches, it seems legitimate to:

1. Treat the two constructs synonymously. For example, in J. Teece`s view (2009), competencies are supported by routines in functional units and should include

11

KAZIMIERZ KRZAKIEWICZ

SZYMON CYFERT 
underlying discrete business processes and other organisation-wide habits. This indicates the two concepts are to some extent treated as synonyms.

2. Treat the two constructs as significantly different. The basis for the distinction between them could be the way the organisation's competitive advantages are structured in the particular areas of its operations or within the entire product value chain. Many articles define competencies as the entirety of organisational processes and current operations relating to the integrated and co-ordinated allocation of resources and assets. While narrowing the meaning of these two concepts, this approach nevertheless provides some insight into their semantic differentiation.

Accordingly, it can be concluded that the difference between "competencies" and "capabilities" stems from the difference in their level of reference. An organisation may have capabilities that would allow it to handle business processes effectively or add value to products and services for its customers, but they will only become competencies once they are put to use. The crux of the problem is in the effective use of capabilities and resources in business operations. In this view, competencies are capabilities that are used in practice. The approach reveals intra-organisational "capabilities" and "competencies" which are distinguished from resources when they cannot be obtained through a purchase.

\section{Operational capabilities and dynamic capabilities}

Different schools of thought in strategic management have come up with several attempts to classify organisational capabilities. The most-well known classification is that proposed by J. Teece, H. Pizano and E. Shuen (1997) who divided capabilities into operational and dynamic ones. While operational (functional) capabilities enable an organisation to carry out routine operations in its day-to-day activities, dynamic capabilities are used to build, integrate and reconfigure operational capabilities.

"Dynamic capabilities" came into focus because of the publications of D. Teece and his associates (Teece et al. 1997) which showed that an organisation's potential is reflected in how it integrates and reconfigures its internal and external competencies to make sure they can match a turbulent and unpredictable environment. An organisation should build and modify its resources and competencies as required by its changing environment as this is how it can maintain optimal competitiveness in a long-term perspective. Capabilities, on the other hand, should be thought of as changeable internal 
and external habits of an organisation, and its managerial and functional competencies.

The table below presents a selection of research approaches to dynamic capabilities.

Table 1. Selected research approaches to dynamic capabilities

\begin{tabular}{|c|c|c|}
\hline Approach & Key ideas & $\begin{array}{l}\text { Major } \\
\text { proponents }\end{array}$ \\
\hline $\begin{array}{l}\text { Integrative } \\
\text { approach }\end{array}$ & $\begin{array}{l}\text { A dynamic dimension is introduced within an organisation } \\
\text { which allows to improve its capabilities in a rapidly changing } \\
\text { environment. The organisation's structure and assets are gradually } \\
\text { in response to changes in its environment. } \\
\text { Organisational assets are transformed through gradual } \\
\text { improvement. If models of organisational behaviour are adapted } \\
\text { continuously, their reproductive capability may be lost. }\end{array}$ & $\begin{array}{l}\text { D. Teece } \\
\text { E. Shuen } \\
\text { H. Pizano }\end{array}$ \\
\hline $\begin{array}{l}\text { Radical } \\
\text { dynamisation } \\
\text { approach }\end{array}$ & $\begin{array}{l}\text { Capabilities of a "total learning organisations" are developed; } \\
\text { organisational capabilities are transformed into renewal/ } \\
\text { reproduction capabilities and ability to respond to rapid changes } \\
\text { in unpredictable market expectations, allowing the organisation to } \\
\text { achieve competitive advantage. Competitive advantage is gained } \\
\text { due to effective learning processes and operational flexibility in an } \\
\text { extremely competitive environment. }\end{array}$ & $\begin{array}{l}\text { J. Martin } \\
\text { K. Eisenhardt }\end{array}$ \\
\hline $\begin{array}{l}\text { Innovation } \\
\text { routine } \\
\text { approach }\end{array}$ & $\begin{array}{l}\text { New decision-making models are created using innovation } \\
\text { routines which are based on dynamic capabilities. The positive } \\
\text { outcome of innovation routines should be to overcome the lack of } \\
\text { flexibility in organisational capabilities. }\end{array}$ & $\begin{array}{l}\text { S. Winter } \\
\text { M. Zollo }\end{array}$ \\
\hline
\end{tabular}

Source: Teece, Pizano, Shuen 1997, Eisenhardt, Martin 2000, Zollo, S. Winter 2002

Numerous strategic management theoreticians have attempted to assess the extent to which organisational capabilities improve performance or have undertaken research to evaluate their impact on business operations. For example, Abraham Carmeli (Carmeli 2004) studied 90 Israeli firms using J. Barney's matrix in order to determine interrelationships between their intangible resources and strategic growth. The research managed to link specific groups of resources to the achievement of sustained competitive advantage by organisations without delineating a precise boundary between "resources" and "capabilities". Interesting research insights are also provided by K. Zott who used simulation modeling methods to determine how the dynamic capabilities of firms may be linked to firm performance within an industry (Zott 2003). 
On analysis, the following key ideas can be identified for various research approaches to dynamic capabilities:

1. Because of the differences between collections of resources and capabilities in different areas of business operations, it is extremely difficult in practice to assess diverse firms.

2. It is impossible to evaluate the dynamic capabilities of a specific organisation without assessing the parameters of its environment.

3. It is only possible to identify the dynamic capabilities of an organisation to address its environment if the performance-based approach and derivative data are used.

4. Dynamic capabilities are closely correlated to the resources and competencies of an organisation and are not limited to transformation of its organisational capabilities.

This provides the basis for the conclusion that dynamic capabilities can be thought of as the capabilities and habits of an organisation which give it the capacity to build, integrate and reconfigure its core competencies to match the requirements of a changing environment and as such provide it with strategic flexibility. Dynamic capabilities should address a firm's relationships with the environment and develop its business processes in a way that maximises the synergic effect of the specific configuration of its organisational resources (see table 2).

Table 2. Types of dynamic capabilities

\begin{tabular}{|c|c|c|c|}
\hline $\begin{array}{l}\text { Capability to } \\
\text { analyse market and } \\
\text { industry situation }\end{array}$ & $\begin{array}{l}\text { Capability to reconfigure } \\
\text { resources }\end{array}$ & $\begin{array}{l}\text { Capability to build } \\
\text { relationships }\end{array}$ & Capability to respond \\
\hline $\begin{array}{l}\text { - Product } \\
\text { innovations } \\
\text { - Analysis of } \\
\text { competitors } \\
\text { - Taking advantage } \\
\text { of Industry trends } \\
\text { - Building effective } \\
\text { product portfolio }\end{array}$ & $\begin{array}{l}\text { - Developing integration } \\
\text { and coordination habits } \\
\text { - Increasing the value of } \\
\text { asset systems } \\
\text { - Knowledge } \\
\text { management } \\
\text { - Decentralisation } \\
\text { - Effective human } \\
\text { resource policy } \\
\text { - Increased synergy } \\
\text { effects for business } \\
\text { process and assets }\end{array}$ & $\begin{array}{l}\text { - Relationships } \\
\text { with government } \\
\text { institutions } \\
\text { - Relationships with } \\
\text { suppliers and } \\
\text { customers } \\
\text { - Relationships with } \\
\text { local institutions } \\
\text { - Building capital/ } \\
\text { equity relationships }\end{array}$ & $\begin{array}{l}\text { - } \text { Preventing } \\
\text { competitive attacks } \\
\text { - Protecting asset } \\
\text { takeover and } \\
\text { imitation } \\
\text { - Information security } \\
\text { and PR } \\
\text { - Building anti-crisis } \\
\text { strategies and } \\
\text { reserve systems }\end{array}$ \\
\hline
\end{tabular}

Source: author's own compilation 
Based on our assessment of a number of high-performing Polish businesses, the following key elements of dynamic capabilities can be identified: knowledge management; organisational learning; innovation; ability to change; entrepreneurial orientation; flexible logistic processes; staff ability to change; ability to protect assets; fast marketing response to market challenges; flexible organisational structure; information system security; flexible supply chain structure.

K.M. Eisenhardt says that dynamic capabilities can be thought of as combinations of simpler capabilities and related routines, some of which may be foundational to others and form a sort of a hierarchy (Eisenhardt, Martin 2000). Based on this approach, the present study proposes the following positioning of dynamic capabilities within the hierarchy of organisational capabilities: operational capabilities are those capabilities that are typical of the majority of firms within an industry; dynamic capabilities, on the other hand, are those that lay at the foundation of a firm's competitive advantage. The distinction is based on a type of competitive differentiation, that is to say, it stems from the level of competitiveness those capabilities provide. Accordingly, we believe that dynamic capabilities allow a firm to build and reconfigure its core competencies in line with changes in its environment. That means that tacit knowledge, which makes imitation difficult, can be a source of the firm's competitive advantage derived its dynamic capabilities. As such, dynamic capabilities are placed at a higher level than operational capabilities within the organisational hierarchy.

Originally, the concept of core competencies (Hamel, Prahalad 1990) related to competencies that provide access to a wide variety of markets, make a significant contribution to the benefits of end products, and can effectively prevent competitors from imitating products. This meant that the managers' attention was focused on the extent of the firm's contribution to the benefits of their end products or their effective manufacture. However, the essence of core competencies and their role as a source of the firm's competitiveness may lie far beyond mere products or services. Understandably, how a specific core competence can be used is limited by the firm's established business model and its configuration of resources and competencies. That said, the firm's continuous strategic choice-making process and its dynamic capabilities should improve its performance and quality of its operations, and they should also make reconfigurations and search for new sources of core competencies more effective.

In conclusion, we propose a wider approach to defining "core competencies", that is one in which they are thought of as the integrated knowledge and behavioural patterns in specific industries, and as the mechanism of relationship- 
building with stakeholders through an effective use of dynamic capabilities. Core competencies are a source of economic, managerial and relational rent and as such determine the firm's long-term competitive advantage. Defined in this way, core competencies provide the synergic effect of resource and competence configuration, and are founded not only on unique resources, market orientation or organisational capabilities, but also on appropriate relationships with different business actors, including informal ones.

Based on these considerations, the figure below presents a firm's strategic choicemaking process.

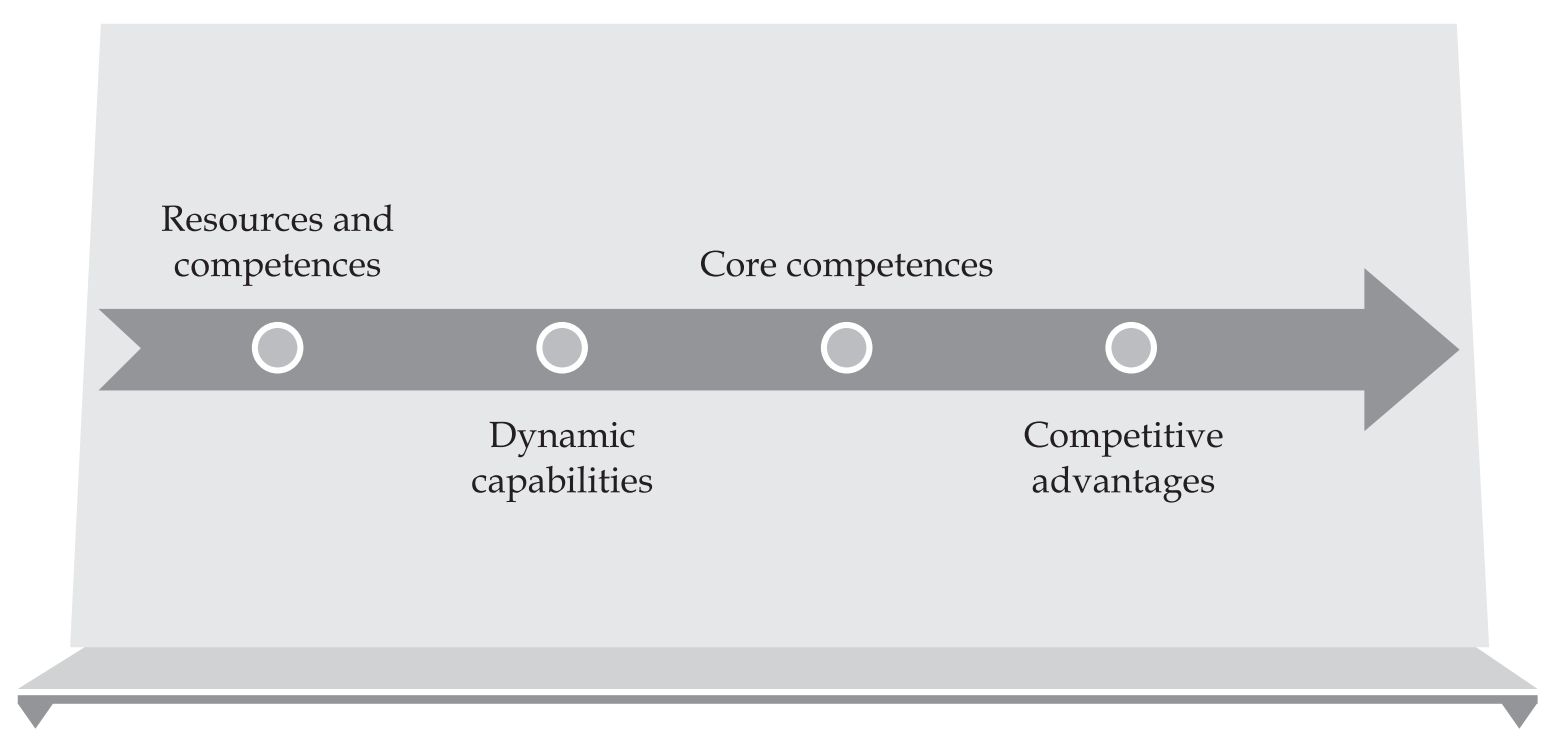

Figure 1. Strategic choice-making process in an organisation

Source: Teece, Pizano, Shuen 1997, Eisenhardt, Martin 2000, Zollo, S. Winter 2002

\section{Conclusion}

The following three conclusions can be made based on our discussion above. Firstly, for an organisation to achieve high performance, its strategic choicemaking process must be continuous. Such continuity must also be ensured in acquiring, building and reproducing core competencies. Research on strategic choice-making in a dynamic competitive environment should go beyond the general resource-based view and allow to identify dynamic capabilities that are created as part of a complex process of building a unique collection of effective resources. Due account should also be taken of the fact that turbulent 
and unpredictable environment means an organisation cannot hold and use inimitable resources over a long term to secure competitive advantage.

Secondly, an increasing importance of the time factor in a changing competitive environment, and the need for fast response to environmental changes, mean that an organisation has to build new dynamic capabilities that would allow it to reconfigure its resources, processes and relationships.

Thirdly, it can be noted that improved competitiveness is usually achieved thanks to unique resources and leadership in core rather than basic competencies. In a competitive market, it is not sufficient to deliver high-quality products to customers; a firm also needs to build its core competencies which, once combined, are transformed into competitive advantages. Based on our discussion, it should also be pointed out that there is no empirical basis to assess Polish firms in terms of their dynamic capabilities.

That said, based on a comparative analysis of Polish firms in terms of their competitiveness (Gorynia and others, 2011), one could conclude that what differentiates them and lets them achieve high performance are higher-level capabilities, that is to say, dynamic capabilities that are key if the firm is to use its internal potential effectively. Unfortunately, it is difficult to identify and assess dynamic capabilities of Polish firms and evaluate their role in strengthening their competitive positions. This is because of the tacit nature of organisational knowledge and strategic management, which makes it impossible to systematise major factors that affect the dynamic capabilities of Polish firms and their core competence building processes. This opens a field for further research.

\section{Summary}

\section{Dynamic capabilities in strategic choice processes within organisations}

Dynamic capabilities are an essential theoretical construct that is useful for understanding the phenomenon of competition. Still, in spite of the apparent popularity of this subject, the existing management literature could do with more studies into processes that shape dynamic capabilities.

The purpose of this article is to systematise different approaches to the dynamic capabilities concept as they are found in the existing literature, with a particular focus on its relevance to modern-day organisations as a tool to increase their competitiveness. The other goal is to discuss two issues that are critical to the dynamic capabilities concept. Firstly, what are the conditions for the

17

KAZIMIERZ KRZAKIEWICZ

SZYMON CYFERT 
predominant role of dynamic capabilities in the area of strategic management? Secondly, can the dynamic capabilities concept be treated as an underlying theoretical and methodological framework for strategic choices in modern-day organisations?

Key words: Dynamic capabilities, operational capabilities.

\section{Streszczenie}

\section{Dynamiczne zdolności $w$ procesach strategicznych wyborów organizacji}

Dynamiczne zdolności stanowią istotny, teoretyczny konstrukt przydatny dla zrozumienia zjawiska konkurencji. Jednak mimo pozornie dużej popularności zagadnień związanych $\mathrm{z}$ problematyką dynamicznych zdolności, w literaturze przedmiotu z obszaru nauk o zarządzaniu brakuje opracowań poświęconych badaniom nad procesami kształtowania dynamicznych zdolności.

W opracowaniu podjęto próbę przeprowadzenia systematyzacji przedstawianych $\mathrm{w}$ literaturze przedmiotu podejść do opisu istoty koncepcji dynamicznych zdolności, ze szczególnym uwzględnieniem jej znaczenia dla podnoszenia poziomu konkurencyjności współczesnych organizacji, a także przeprowadzanie dyskusji nad dwoma, krytycznymi dla koncepcji dynamicznych zdolności zagadnieniami. Po pierwsze, jakie są przesłanki dominacji koncepcji dynamicznych zdolności w obszarze zarządzania strategicznego? Po drugie, czy koncepcja dynamicznych zdolności może być traktowana jako teoretyczno-metodologiczna baza strategicznych wyborów współczesnych organizacji?

\section{Slowa \\ kluczowe: Dynamiczne zdolności, zdolności operacyjne.}

\section{References}

1. Amit R., Schoemaker C. J. (1993), Strategic Assets and Organizational Rent, "Strategic Management Journal", No. 14, pp. 33-46.

2. Andrews, K. (1980), The Concept of Corporate Strategy, 2nd Edition, DowJones Irwin. 
3. Barney J. B. (1991) Firm resources and sustained competitive advantage, "Journal of Management", No. 17, pp. 99-100.

4. Carmeli A. (2004), Assessing Core Intangible Resources, "European Management Journal", Vol. 22, No. 1, pp. 110-122.

5. Dierickx J., Cool K. (1999), Asset stock accumulation and sustainability of competitive advantage, "Management Science", No 35, pp. 1504-1511.

6. Eisenhardt K.M., Martin J.A. (2000), A Dynamic Capabilities: What Are They?, "Strategic Management Journal", Vol 21, pp. 1105-1121.

7. Gorynia M., Dzikowska M., Jankowska B., Pietrzykowski M., Tarka P. (2011), Przystapienie Polski do strefy euro a międzynarodowa konkurencyjność i internacjonalizacja polskich przedsiębiorstw, „Ekonomista”, No. 4, pp.471-491.

8. Helfat C. E., (2009), Understanding dynamic capabilities: progress along a developmental path, "Strategic Organization", No. 7, pp. 91-102.

9. Kogut B., Zander U., Knowledge of the firm, Combinative Capabilities, and the Replication of Technology, "Organization Science" 2002, No. 3 (3), pp. $383-$ 397.

10. Loasby B. (1998), The Organization of Capabilities, "Journal of Economic Behavior \& Organization", Vol 35, pp. 139-160.

11. Nelson R., Winter S.G. (1982), An Evolutionary Theory of the Economic Change, Cambridge, Harvard University Press.

12. Prahalad C.K., Hamel G. (1900), The Core Competence of the Corporation, "Harvard Business Review" 1990, No. 68 (3), pp. 79-91.

13. Richardson G.B., (1972), The Organisation of Industry, "Economic Journal", Vol. 82, No. 327, pp. 883-896.

14. Sanchez, R., Heene, A. and Thomas, H. (1996), Towards the theory and practice of competence-based competition, Sanchez, R., Heene, A. and Thomas, H. (Eds.) Dynamics of competence-based competition: theory and practice in the new strategic management, London, Elsevier.

15. Teece D. J., Pisano G., Shuen A. (1997), Dynamic Capabilities and Strategic Management, "Strategic Management Journal", No. 18 (7), pp. 509-534.

16. Teece D.J. (2009), Explicating dynamic capabilities: the nature and micro foundations of sustainable enterprise performance, "Strategic Management Journal", No. 28, pp. 1319-1350.

17. Wernerfelt B. (1984), A resource - based view of the firm, "Strategic Management Journal", No. 2, pp. 171-180.

18. Winter S.G. (2003), Understanding dynamic capabilities, "Strategic Management Journal", No. 24, pp. 991-995.

19. Zollo M., Winter S.G. (2002), Deliberate learning and evolution of dynamic capabilities, "Organization science", No. 13, pp. 339-351.

20. Zott C. (2003), Dynamic Capabilities and the Emergence of Intra-Industrial Differential Firm Performance, "Strategic Management Journal", No. 24, pp. 97-125. 